\title{
Attitudes and Practices of Operating Room Nurses toward COVID-19 in Turkey
}

\author{
Filiz Öğce Aktaşs ${ }^{1}$ (D) , Hale Turhan Damar²
}

'Department of Nursing, Faculty of Health Science, Izmir University of Economics, Izmir, Turkey

${ }^{2}$ Elderly Care Program, Health Services Vocational School, Izmir Democracy University, Izmir, Turkey

\section{Filiz ÖĞCE AKTAŞ}

Hale TURHAN DAMAR
Correspondence: Hale Turhan Damar Elderly Care Program, Health Services Vocational School, Izmir Democracy University, Izmir, Turkey

Phone: +905074434926

E-mail: hale.turhan1986@gmail.com
Received
: 14 June 2021
Accepted
: 2 December 2021

\begin{abstract}
The aim of this study was to determine attitudes and practices of operating room nurses toward COVID-19. The study had a descriptive design. The study sample included 210 operating room nurses working between June and 0 ctober 2020. The rate of the operating room nurses infected with COVID-19 disease was $12.4 \%$. In this study, $91 \%$ of the nurses considered that insufficient precautions were taken against the COVID-19 pandemic in the operating rooms. $44.3 \%$ of the nurses wore an $\mathrm{N} 95$ respirator for the mean duration of $8.6+4.7$ hours in operating room and $45.2 \%$ reused their masks. The most frequent precaution was disinfection of the containers for infected material using agents containing active chloride 5.000 $\mathrm{mg} / \mathrm{L}$ for 30 minutes at the rate of $95.2 \% .81 \%$ of operating room nurses were fearful of contracting COVID-19 infection, and $96.2 \%$ were fearful of transmitting the disease to their families. The study found that most nurses considered that insufficient precautions were taken against the COVID-19 pandemic in the operating rooms. In addition, one-third of operating room nurses stated that they had difficulty adapting during the process in COVID-19. Hospital administration should provide education at regular intervals for operating room nurses about COVID-19 and prepare workflow algorithms to facilitate their compliance.
\end{abstract}

Keywords: COVID-19, Operating room nurses, Practices, Attitudes

\section{Türkiye'de Ameliyathane Hemşirelerinin COVID-19'a Karşı Tutum ve Uygulamaları}

ÖZET

Bu çalışmanın amacı ameliyathane hemşirelerinin COVID-19'a yönelik tutum ve uygulamalarınının belirlenmesidir. Araştırma tanımlayııı bir tasarımdı Araştırmanın örneklemini Haziran-Ekim 2020 tarihleri arasında görev alan 210 ameliyathane hemşiresi oluşturdu. COVID-19 hastalığı tanısı konulan ameliyathane hemşirelerinin oranı \%12.4'idi. Çalışmada hemşirelerin \%91'i ameliyathanelerde COVID-19 salgınına karşı yeterli önlem alınmadığını belirtti. Hemşirelerin \%44,3'ü ameliyathanede ortalama 8,6+4,7 saat süreyle N95 maskesi kullandığını ve \%45,2'si maskelerini tekrar kullandığını belirttti. En sık alınan önlem, enfekte olmuş malzeme için kapların \%95,2 oranında aktif klorür 5.000 mg/L 30 dakika süreyle dezenfeksiyonuydu. Ameliyathane hemşirelerinin \%81'i COVID-19 enfeksiyonuna yakalanmaktan ve \%96,2'si hastalığı ailelerine bulaştırmaktan korkuyordu. Bu araştırmada, hemşirelerin çoğunun COVID-19 pandemisine karşı yetersiz önlem alındığını düşündüğü saptandı. Ayrıca ameliyathane hemşirelerinin üçte biri COVID-19'da süreçiçinde uyum sağlamakta zorlandıklarını belirtti. Hastane yönetimlerinin COVID-19 salgınına yönelik ameliyathane hemşirelerine düzenli aralıklarla eğitim vermesi ve uyumlarını kolaylaştıracak iş akış algoritmalarını hazırlamaları önerilmektedir.

Anahtar Kelimeler: COVID-19, Ameliyathane hemşireleri, Uygulamalar, Tutumlar 
$\mathbf{T}$ he coronavirus disease 2019 (COVID-19) is a contagious respiratory tract disease caused by severe acute upper respiratory syndrome coronavirus-2 (SARS-CoV-2) (1). It appeared in Wuhan, China, in 2019, quickly spread worldwide, becoming a pandemic (2). At the time of writing, about 80 million people had been infected, and 2 million had died in 220 countries, according to data from the World Health Organization (WHO) (3). Diagnosis of the first COVID-19 case was confirmed in Turkey on 10 March 2020. After that, as the number of the tests increased, so did the number of the cases. Due to the increased number of cases, various isolation measures were taken, including lockdown. On 24 December 2020, the total number of the people infected with the virus reached 2.100.712, and 19.115 people had died (4). As the COVID-19 outbreak quickly spread throughout the world, the governments, health professionals and researchers in the affected countries developed policies and procedures to provide appropriate treatment and to prevent waves of rapid recurrences (5-7).

The risk of COVID-19 transmission is high in operating rooms because of the presence of patients with suspected or confirmed diagnosis of this disease, the use of highrisk equipment (surgical devices and anesthetic gases etc.) $(8,9)$ and the closed and confined working area (10). It has been emphasized in the literature that elective surgeries should be postponed, emergency surgeries only should be performed (traumas, cancer or cardiac surgery etc.) (7) and the necessary precautions should be taken. It has also been shown that COVID-19 can lead to severe hospital infections, threatening the surgical staff $(11,12)$. Therefore, it is important to plan and take precautions against COVID-19 regarding the following issues: use of personal protective equipment (PPE) by the surgical team, the preparation and transport of the patient for surgery, the type of surgery performed (open or laparoscopic), and the type of anesthesia and management of anesthetic gases used during surgery $(8,10,12-14)$. In literature, there have been limited number of studies about practices against COVID-19 in operating rooms, and institutional compliance with these. The aim of this study was to determine attitudes and practices of operating room nurses toward COVID-19.

\section{MATERIAL AND METHODS}

\section{Study Design and Sampling}

This descriptive study was performed in Turkey between June 15, 2020 and October 30, 2020.
The study population included 1456 ORNs, who were members of Turkish Operating Room Nurses Association (TORN). Inclusion criteria were as follows: at least 18 years of age, able to read and write in Turkish, working in the operating room, and voluntarily participating in the study. In the determination of sample size, the formula for sample sizes within a known universe was used. The universe of the study consisted of 1456 ORNs, who were members of Turkish Operating Room Nurses Association. According to the formula of sample size within a known universe, the sample size was calculated to be 190 ORNs with a $95 \%$ confidence interval and $5 \%$ error margin. In case of the loss of the participants, the sample size was increased by 30, and 210 ORNs formed the study sample.

\section{Data Collection and Analysis}

The data were collected using a data collection form were developed by the researchers in light of the relevant literature (6-9). The study was prepared based on universal recommendations in the literature. There is not a reliable and valid scale evaluating the practices and compliance against COVID-19 disease. A pre-application was made on 5 nurses (three ORNs and two academician nurses) to determine the comprehensibility of the form. The data collection form was created electronically using Google Form. Then, this form was submitted to ORNs members of TORNA online using communication networks (e-mail, social media, etc.). Those who volunteered were invited to participate in the study.

Data collection was performed online by using a general characteristic form for ORNs and Attitudes and Practices in Operating Room Nurses toward Covid-19 Questionnaire.

General Characteristics Form for Operating Room Nurses; The form was composed of seven questions about age, gender, education, duration of overall work experience, workplace, current city, and duration of work experience in the current city.

Attitudes and Practices of Operating Room Nurses toward COVID-19 Questionnaire; The questionnaire was developed in light of the recommendations in the guidelines for COVID-19, and is composed of 55 questions about COVID-19 infection attitudes and practices in operating rooms, and compliance with these $(6-9,14)$.

Statistical Package Program for Social Sciences 22 (IBM Corporation, New York) was used to analyze the data. Data about ORNs' sociodemographic features were performed using measures of numbers, percentages and mean values. 


\section{Ethical Considerations}

This study was performed in accordance with the principles of the Declaration of Helsinki. Permission was taken from the Scientific Research Platform of the Ministry of Health (2020-07-10T14_49_31) and ethical approval was obtained from the Clinical Studies Ethics Committee of University (approval no. 2020/27, 26.06.2020). Participants joined the study after reading the informed consent form and checking the box that read "I fully agree to participate in this study".

\section{RESULTS}

The study comprised 210 ORNs from 123 different hospitals in 35 cities. There are four categories of hospital in Turkey: state hospitals, private hospitals, education and research hospitals, and university hospitals. Of all the ORNs in this study, 92 (43.8\%) were in state hospitals, 46 (21.9\%) in education and research hospitals, 41 (19.5\%) in university hospitals and $31(14.8 \%)$ in private hospitals. The mean age of the nurses was $38.75 \pm 6.98$ years $(\min =23, \max : 55)$ and the mean duration of operating room work experience was $17.61 \pm 9.07$ years ( $\mathrm{min}=1$, $\max =38$ ). $85.7 \%$ of the nurses were female. $84.3 \%$ had a bachelor's degree and $14.3 \%$ had an MSc degree. $62.4 \%$ of the nurses reported working 8 hours in a day (Table 1).
81.9\% participated in surgery for a COVID-19 patient and $15.7 \%$ worked in an operating room transformed into an intensive care unit. $85.2 \%$ of the nurses received education about precautions taken in operating rooms against COVID-19 pandemic and $82.4 \%$ of these received this education in the hospital where they worked. $44.3 \%$ of the nurses wore an $\mathrm{N} 95$ respirator for the mean duration of 8.6 \pm 4.7 hours ( $\min =6, \max =24$ ) in operating room, $45.2 \%$ reused their masks and of these (only) $36.7 \%$ checked permeability of their masks. $91 \%$ of the nurses found insufficient precautions against COVID-19 in the theater and $12.4 \%$ of the nurses reported being infected with COVID-19. In addition, $81.9 \%$ were fearful of contracting COVID-19 infection, and $96.2 \%$ were fearful of transmitting the disease to their families. The most frequent precaution was disinfection of the containers for infected material using agents containing active chloride $5.000 \mathrm{mg} / \mathrm{L}$ for 30 minutes at the rate of $95.2 \%$. Three quarters of operating room nurses state that if present, macroscopic contamination such as blood and bodily fluids are removed and cleaned before disinfection procedures. About half of ORNs stated that the surfaces of all the medical devices are cleaned with $1000 \mathrm{mg} / \mathrm{L}$ chloride and this must be repeated three times daily or when there is contamination and the air in spaces occupied by the staff is disinfected with a plasma air purifier or by turning on ultraviolet lamps for one hour.

\begin{tabular}{|c|c|c|c|}
\hline Descriptive Characteristics & $X+S D$ & Min & Max \\
\hline Age & 38.75 & 23 & 55 \\
\hline \multirow[t]{2}{*}{ Years of experience in the operating room } & 17.61 & 1 & 38 \\
\hline & Category & $\mathbf{n}$ & $\%$ \\
\hline \multirow{2}{*}{ Gender } & Female & 180 & 85.7 \\
\hline & Male & 30 & 14.3 \\
\hline \multirow{3}{*}{ Education } & High school + Two-year university program & 33 & 15.7 \\
\hline & University & 147 & 70 \\
\hline & Master of Science & 30 & 14.3 \\
\hline \multirow{4}{*}{ Years of experience in the operating room } & 5 years or less & 28 & 13.3 \\
\hline & $6-10$ & 23 & 11 \\
\hline & 11-15 & 35 & 16.7 \\
\hline & 16 years and over & 124 & 59 \\
\hline \multirow{4}{*}{ Type of hospital } & State Hospital & 92 & 43.8 \\
\hline & Research and Education Hospital & 46 & 21.9 \\
\hline & University Hospital & 41 & 19.5 \\
\hline & Private Hospital & 31 & 14.8 \\
\hline \multirow{2}{*}{ Daily working time } & 8 hours & 131 & 62.4 \\
\hline & More than 8 hours & 79 & 37.6 \\
\hline
\end{tabular}


In addition, $93.3 \%$ of the nurses reported that the whole surgical team wore an N95 or FFP2/FFP3 respirator, 93.8\% reported using only conventional methods for decontamination and sterilization of the equipment, and $81.9 \%$ received education about procedures for putting on and removing PPE. However, $75.2 \%$ of the nurses reported the failure to measure body temperatures of all the staff with an electronic thermometer and record these electronically twice daily and $52.4 \%$ of the nurses could not access spare masks when their masks were extremely dirty or damaged, or when these caused difficulty in breathing. In addition, $39 \%$ of the nurses were not certain that all the patients presenting to hospital were administered the questionnaire developed by the Turkish Ministry of Health to determine suspected or confirmed case of COVID-19 (Table 2).

\section{Table 2. Attitudes and Practices of Operating Room Nurses toward COVID-19}

\begin{tabular}{|c|c|c|c|c|c|c|}
\hline & \multicolumn{2}{|c|}{ Yes } & \multicolumn{2}{|c|}{ No } & \multicolumn{2}{|c|}{ Not Know } \\
\hline & $\mathbf{n}$ & $\%$ & $\mathbf{n}$ & $\%$ & $\mathbf{n}$ & $\%$ \\
\hline $\begin{array}{l}\text { 1. Have you taken part in surgeries for patients with possible or definitive } \\
\text { COVID-19? }\end{array}$ & 172 & 81.9 & 38 & 18.1 & & \\
\hline $\begin{array}{l}\text { 2. Some operating rooms had to be converted into intensive care units for } \\
\text { COVID-19 cases during the pandemic. Was the case in operating room where you } \\
\text { work? }\end{array}$ & 33 & 15.7 & 177 & 84.3 & & \\
\hline $\begin{array}{l}\text { 3. Some operating rooms had to be converted into intensive care units for } \\
\text { COVID- } 19 \text { cases during the pandemic. Did you work in these units? }\end{array}$ & 58 & 27.6 & 152 & 72.4 & & \\
\hline $\begin{array}{l}\text { 4. When you take/took part in care for COVID-19 cases, do/did you stay isolated, } \\
\text { away from your family? }\end{array}$ & 69 & 32.9 & 97 & 46.2 & 44 & 21 \\
\hline $\begin{array}{l}\text { 5. Have you received education about precautions against COVID-19 in operating } \\
\text { rooms? }\end{array}$ & 158 & 75.2 & 52 & 24.8 & & \\
\hline 6. Do you check the permeability of your mask before each use? & 77 & 36.7 & 91 & 43.3 & 42 & 20 \\
\hline 7. I think precautions taken against COVID-10 are sufficient. & 19 & 9 & 191 & 91 & & \\
\hline 8. I am afraid of contracting COVID-19. & 172 & 81.9 & 38 & 18.1 & & \\
\hline 9. I am afraid of transmitting COVID-19 to members of my family. & 202 & 96.2 & 8 & 3.8 & & \\
\hline $\begin{array}{l}\text { 10. All patients presenting to hospital are administered the questionnaire prepared } \\
\text { by the Ministry of Health to determine possible or definitive COVID-19 cases. }\end{array}$ & 101 & 48.1 & 27 & 12.9 & 82 & 39 \\
\hline $\begin{array}{l}\text { 11. Health professionals are either assigned to care to COVID-19 cases, or those } \\
\text { offering care to other patients, or they give care to both groups of patients. }\end{array}$ & 171 & 81.4 & 34 & 18.6 & & \\
\hline $\begin{array}{l}\text { 12. Health care workers wearing insufficient PPE are not allowed to work while the } \\
\text { infectious diseases team evaluates them. }\end{array}$ & 90 & 42.9 & 75 & 35.7 & 45 & 21.4 \\
\hline $\begin{array}{l}\text { 13. Body temperatures of all the staff are measured with a digital thermometer and } \\
\text { recorded in an electronic database. }\end{array}$ & 45 & 21.4 & 158 & 75.2 & & \\
\hline $\begin{array}{l}\text { 14. All cleaning staff receives education about the rules that they have to obey to } \\
\text { prevent COVID- } 19 \text {. }\end{array}$ & 130 & 61.9 & 31 & 14.8 & 49 & 23.3 \\
\hline $\begin{array}{l}\text { 15. Elective surgeries have been postponed and only emergency surgeries (for } \\
\text { traumas, cancers, aneurism and appendicitis etc.) are performed. }\end{array}$ & 89 & 42.5 & 121 & 57.6 & & \\
\hline $\begin{array}{l}\text { 16. Work flow algorithms directed towards prevention of COVID-19 in the } \\
\text { operation rooms are available }\end{array}$ & 158 & 75.2 & 52 & 24.8 & & \\
\hline 17. There are suitable places where the staff can put on and take off their PPE & 142 & 67.6 & 68 & 32.4 & & \\
\hline $\begin{array}{l}\text { 18. Education about how to put on and take off PPE has been/is offered to all the } \\
\text { staff. }\end{array}$ & 172 & 81.9 & 38 & 18.1 & & \\
\hline $\begin{array}{l}\text { 19. Information about COVID-19 pandemic is available on the hospital website or } \\
\text { sent to all through email. }\end{array}$ & 166 & 79 & 20 & 9.5 & 24 & 11.4 \\
\hline $\begin{array}{l}\text { 20. Patients scheduled to have surgery are immediately operated without losing } \\
\text { time considering whether these patients may have COVID-19. }\end{array}$ & 130 & 61.9 & 80 & 38.1 & & \\
\hline $\begin{array}{l}\text { 21. Doctors and nurses wear all PPE (caps, N95 or FFP respirators, googles or } \\
\text { facial shields, two pairs of gloves and shoes covering feet completely) during } \\
\text { examination of the patient before surgery. }\end{array}$ & 121 & 57.6 & 60 & 28.6 & 29 & 13.8 \\
\hline $\begin{array}{l}\text { 22. Patients with possible or definitive COVID-19 are transferred from the ward } \\
\text { to the operating room by a nurse wearing N95 or FFP respirators, googles/facial } \\
\text { shields, water-proof aprons and overshoes completely covering the feet. }\end{array}$ & 124 & 59 & 56 & 26.7 & 30 & 14.3 \\
\hline
\end{tabular}


Table 2. Attitudes and Practices of Operating Room Nurses toward COVID-19 (Continuation of Table 2)

\begin{tabular}{|c|c|c|c|c|c|c|}
\hline & \multicolumn{2}{|c|}{ Yes } & \multicolumn{2}{|c|}{ No } & \multicolumn{2}{|c|}{ Not Know } \\
\hline & $\mathbf{n}$ & $\%$ & $\mathbf{n}$ & $\%$ & $\mathbf{n}$ & $\%$ \\
\hline $\begin{array}{l}\text { 23. There is a small, isolated surgical complex in the operating room accessed } \\
\text { through a separate entrance to perform surgeries for patients with possible or } \\
\text { definitive COVID-19. }\end{array}$ & 134 & 63.8 & 76 & 36.2 & & \\
\hline 24. All unutilized equipment is taken out of the operating room. & 145 & 69 & 56 & 26.7 & & \\
\hline $\begin{array}{l}\text { 25. All the members of the surgical team wear a surgical gown, a water-proof suit } \\
\text { and a sterilized surgical apron, in that order. }\end{array}$ & 170 & 81 & 40 & 19 & & \\
\hline 26. All the members of the surgical team wear $\mathrm{N} 95$ or FFP2/FFP3 respirators & 196 & 93.3 & 14 & 6.7 & & \\
\hline 27. To extend the use of an N95 respirator, we wear a surgical mask over it. & 186 & 88.6 & 24 & 11.4 & & \\
\hline 28. All the members of the surgical team wear protective goggles. & 163 & 77.6 & 47 & 22.4 & & \\
\hline 29. The staff members wear a facial shield when aerosols spread during surgeries. & 178 & 84.8 & 32 & 15.2 & & \\
\hline $\begin{array}{l}\text { 30. The number of the health professionals in the surgical team is kept at minimum } \\
\text { and the mobility of the surgical team inside and outside the operating room is } \\
\text { minimized. }\end{array}$ & 188 & 84.8 & 22 & 15.2 & & \\
\hline $\begin{array}{l}\text { 31. The surgical team members do not wear accessories like a wrist watches, rings } \\
\text { or bracelets during surgeries in the pandemic. }\end{array}$ & 141 & 67.1 & 69 & 32.9 & & \\
\hline $\begin{array}{l}\text { 32. The surgical team members keep such devices as phone or pager in plastic } \\
\text { shields. }\end{array}$ & 108 & 51.4 & 76 & 36.2 & 26 & 12.4 \\
\hline $\begin{array}{l}\text { 33. The gloves worn under the sterilized surgical gloves are washed with antiviral } \\
\text { agents or alcohol-based antiseptics. }\end{array}$ & 130 & 61.9 & 80 & 38.1 & & \\
\hline $\begin{array}{l}\text { 34. We prefer to use extended cuff gloves reaching well above the wrist during } \\
\text { surgery. }\end{array}$ & 95 & 45.2 & 115 & 54.8 & & \\
\hline $\begin{array}{l}\text { 35. The surgical team members have a shower and change their clothing after } \\
\text { taking off all their PPE. }\end{array}$ & 121 & 57.6 & 89 & 42.4 & & \\
\hline 36. There are intervals of at least two hours after each surgery. & 100 & 47.6 & 82 & 39 & 28 & 13.3 \\
\hline $\begin{array}{l}\text { 37. During the two-hour intervals, the operating room is cleaned three times at } \\
\text { 30-minutes intervals. }\end{array}$ & 84 & 40 & 126 & 60 & & \\
\hline 38. Surgeries are not performed at night if possible. & 115 & 54.8 & 18 & 8.6 & 77 & 36.7 \\
\hline $\begin{array}{l}\text { 39. If patients have no signs of COVID-19 or proven COVID-19, they are not given } \\
\text { treatment for the disease. }\end{array}$ & 168 & 80 & 42 & 20 & & \\
\hline 40. Patients diagnosed as COVID-19 are given treatment for the disease. & 176 & 83.8 & 34 & 16.2 & & \\
\hline 41. Disposable equipment is put in the biological waste bags. & 145 & 69 & 44 & 21 & 21 & 10 \\
\hline $\begin{array}{l}\text { 42. No additional procedures are needed for decontamination and sterilization of } \\
\text { the surgical equipment, except for normal sterilization procedures. }\end{array}$ & 197 & 93.8 & 13 & 6.2 & & \\
\hline $\begin{array}{l}\text { 43. If present, macroscopic contamination such as blood and bodily fluids are } \\
\text { removed and cleaned before disinfection procedures. }\end{array}$ & 157 & 74.8 & 22 & 10.5 & 31 & 14.8 \\
\hline $\begin{array}{l}\text { 44. The surfaces of all the medical devices are cleaned with } 1000 \mathrm{mg} / \mathrm{L} \text { chloride } \\
\text { and this must be repeated three times daily or when there is contamination. }\end{array}$ & 114 & 54.3 & 70 & 33.3 & 26 & 12.4 \\
\hline $\begin{array}{l}\text { 45. The air in spaces occupied by the staff is disinfected with a plasma air } \\
\text { purifier or by turning on ultraviolet lamps for one hour. }\end{array}$ & 104 & 54.3 & 33 & 12.4 & 73 & 33.3 \\
\hline $\begin{array}{l}\text { 46. Containers for infected material are disinfected with } 5.000 \mathrm{mg} / \mathrm{L} \text { active } \\
\text { chloride for } 30 \text { minutes. }\end{array}$ & 200 & 95.2 & 10 & 4.8 & & \\
\hline $\begin{array}{l}\text { 47. I can access a spare mask when my mask is extremely dirty or damaged or } \\
\text { when I have difficulty breathing. }\end{array}$ & 99 & 47.1 & 111 & 52.9 & & \\
\hline $\begin{array}{l}\text { 48. It was easy to convert the operating room for COVID-19 pandemic in our } \\
\text { hospital. }\end{array}$ & 1102 & 52.4 & 68 & 32.4 & 32 & 15.2 \\
\hline $\begin{array}{l}\text { 49. It was easy to educate the operating room staff, and they readily complied } \\
\text { with the pandemic process. }\end{array}$ & 127 & 60.5 & 83 & 39.5 & & \\
\hline
\end{tabular}




\section{DISCUSSION}

Health professionals are three times more likely to contract COVID-19 compared to the general population (15); the rate of the health professionals with COVID-19 positivity ranges from $1.5 \%$ to $20.7 \%(10,16,17)$. Consistent with the literature, in the present study, $12.4 \%$ of the ORNs were found to have contracted COVID-19.

The main factors increasing the risk of contracting COVID-19 are insufficient precautions for prevention of the infection, and inability of the healthcare systems to manage the pandemic (18). Ti et al. proposed that use of algorithms and protocols about how to deal with COVID-19 cases in operating rooms can reduce the risk of transmission.(8) In the current study, $75.2 \%$ of the ORNs reported that a written work flow was used in the operating rooms, which is congruent with the literature $(8,19)$. Forty-eight-point-one percent of the nurses implemented the questionnaire created by the Ministry of Health to detect possible COVID-19 cases; however, 39\% reported no awareness of the questionnaire. ORNs' lack of awareness may be because this questionnaire is conducted in the preoperative period.

Transmission routes for COVID-19 are coughing, sneezing and spread of large droplets containing viral particles.(20) These droplets can be suspended in the air for a few seconds and can travel a short distance before descending to the ground due to their weight $(21,22)$. However, the droplets may lose their liquid content, diffuse into air and produce aerosols during such procedures as intubation, extubating, tracheal aspiration, use of electrical devices and medical gases and endoscopic examinations (23). These aerosols can remain in the air for as long as three hours, and even longer on surfaces. COVID-19 can result from inhalation of these aerosols or contaminated hands coming into contact with the mouth, nose or eyes (23). Since conventional surgical masks do not protect against these aerosols, it is recommended that N95 or FFP respirators should be utilized (24). In the current study, 93.3\% of the ORNs utilized N95 or FFP2/FFP3 respirators during surgery and $84.8 \%$ also used face shields. The mean duration of wearing masks was $7.6 \pm 4.3$ hours; $44.3 \%$ of the nurses reused their masks and $29.5 \%$ used them for longer period. Reusing a mask refers to wearing the same N95 respirator during surgery for multiple patients and removing it at certain intervals. In many guidelines (CDC, FDA, OSHA, WHO), longer use of masks is recommended rather than reusing the same mask. It is important to adopt the policy of single use of N95 respirators in suspected or confirmed case of COVID-19, since their long-term use or limited reuse poses the risk of droplet infection, of disrupted filtration efficacy, of cross contamination during storage, and of contamination during attachment and removal (7).

Two important needs of the health professionals during the pandemic have been reported as being PPE and adequate rest periods (25). In the present study, about half of the nurses reported being able to access a spare mask. It is stated in the literature that masks are the PPE most frequently needed by health professionals, and that (only) about half of health professionals have access $(26,27)$. Guidelines directed towards reduction of COVID-19 transmission recommend that health professionals are classified either as frontline healthcare workers or others (7). In the current study, $81.9 \%$ of the nurses were frontline health workers. Health organizations should take further precautions in addition to temperature measurements to determine whether health professionals have be exposed to COVID-19. In this study, only $21.4 \%$ of the ORNs reported that their body temperatures were measured with a digital thermometer twice daily.

It is important to plan and implement precautions against the spread of COVID-19 pandemic in operating rooms. In the present study, $81.9 \%$ of the nurses reported receiving education about the appropriate wearing and removal of PPE, $75.2 \%$ reported receiving education about precautions to be taken in operating rooms, and $79 \%$ reported that information about COVID-19 pandemic was available on their hospital website. However, $91 \%$ of the nurses found the precautions taken insufficient, possibly due to their fear of contracting COVID-19. Health professionals experience anxiety due to the sudden outbreak of the pandemic, its rapid spread and lack of information about exposure to and treatment for the disease. Consistent with the literature, the present study revealed that $81.9 \%$ of the nurses feared being infected and $96.2 \%$ feared transmitting the disease to family members. ORNs'limited experience of respiratory tract diseases may lead to greater difficulty in stress management and increased anxiety (28).

It is necessary to take isolation precautions during surgery for COVID-19 cases, in addition to pre-existing measures; it is recommended that ORNs be supplied with third-line precautions (N95 respirators, disposable water-proof aprons, protective googles, face shields and foot protectors) in addition to first-line precautions taken under normal conditions (disposable caps, surgical aprons, medical 
masks and gloves).(29) In the present study, high rates were found for the use of surgical gowns, water-proof suits and sterilized surgical aprons in order (81\%), facial shields (84.8\%), protective googles (77.6\%) and masks (93.3\%), consistent with the results of the relevant studies (19). However, only about half of the nurses' PPE included an N95 or FFP respirator, googles/facial shields, waterproof aprons, and overshoes completely covering the feet while evaluating and transferring suspected or confirmed case of COVID-19.

Postponement of elective surgeries, avoidance of surgery at night and allocation of negative-pressure operating rooms for COVID-19 cases are recommended to prevent cross infection (30). In the current study, $42.5 \%$ of the nurses reported that elective operations were postponed, and $54.8 \%$, that surgeries performed at night were minimized. In fact, $57.6 \%$ of the ORNs said surgeries were not postponed. This may be because cancer and emergency surgeries are more frequently carried out in these hospitals. It can also be associated with the time of data collection, when pandemic-related restrictions were loosened, allowing an increase in the number of surgeries. Forty percent of the nurses in this study noted that surgeries were performed at two-hours intervals, during which the operating rooms were appropriately cleaned. Lack of a sufficient interval between surgeries may lead to improper cleaning of the equipment and increased risk of transmission. Therefore, intervals of at least one-hour between surgeries are recommended so that all surfaces, including screens, keyboards, cables, monitors and anesthesia machines, can be decontaminated (8). In the current study, although about half of the nurses reported unproblematic conversion of the operating rooms for COVID-19 cases. In fact, it was more difficult for hospitals to adapt operation rooms during COVID-19 pandemic, possibly due to inappropriate architectural designs of the operation rooms, staff shortages and financial problems.

To conclude, most of the ORNs reported using PPE and receiving education for it. However, they also considered that the precautions taken were insufficient. ORNs' mean years of operating room experience, combined with their lack of experience providing care for patients with respiratory/droplet infections, may have caused anxiety while offering care to COVID-19 cases. Therefore, it can be recommended that information on precautions against respiratory/droplet infections and management of infected patients should be incorporated into in-service training programs, nursing curricula, and certificate programs for operating room nursing. More than one third of the
ORNs reported difficulties in converting operating rooms during COVID-19 pandemic and adapting to this process. To facilitate the conversion of operating rooms and the adaptation of health professionals, hospital administration should give regular structured education to health professionals and create workflow algorithms.

\section{REFERENCES}

1. Guan W, Ni Z, Hu Y, et al. Clinical characteristics of coronavirus disease 2019 in China. N Engl J Med. 2020;382(18):1708-20.

2. Sohrabi C, Alsafi Z, O'Neill N, et al. World Health Organization declares global emergency: A review of the 2019 novel coronavirus (COVID-19). International Journal of Surgery. 2020;76:71-6.

3. WHO. Coronavirus disease (COVID-19) [Internet]. World Health Organisation. 2020 [cited 2020 Dec 22]. Available from: https:// www.who.int/emergencies/diseases/novel-coronavirus-2019

4. Ministry of Health. Covid19 [Internet]. The Republic of Turkey Ministry. 2020 [cited 2020 Dec 22]. Available from: https://covid19. saglik.gov.tr/

5. Liang T. Handbook of COVID-19 prevention and treatment. The First Affiliated Hospital, Zhejiang University School of Medicine. Compiled According to Clinical Experience. 2020; 68.

6. Dunn D. Adapting protocols for the care of surgical patients during the COVID-19 pandemic. AORN J. 2020;112(1):15-8.

7. Center for Disease Control and Prevention (CDC). Interim infection prevention and control recommendations for healthcare personnel during the coronavirus disease 2019 (COVID-19) pandemic. 2020 [cited 2020 Dec 22]. Available from: https://www.cdc.gov/ coronavirus/2019-ncov/hcp/infection-control-recommendations. html

8. Ti LK, Ang LS, Foong TW, et al. What we do when a COVID-19 patient needs an operation: operating room preparation and guidance. Canadian Journal of Anesthesia. 2020;67:56-8.

9. Yu GY, Lou Z, and Zhang W. Several suggestions of operation for colorectal cancer under the outbreak of Corona Virus Disease 19 in China. Chinese Journal of Gastrointestinal Surgery. 2020;23(3):9-11.

10. Hussain ZB, Shoman H, Yau PWP, et al. Protecting healthcare workers from COVID-19: learning from variation in practice and policy identified through a global cross-sectional survey. Bone Jt Open. 2020;1(5):144-51.

11. Stannard D. COVID-19: Impact on perianesthesia nursing areas. Journal of Perianesthesia Nursing. 2020;35:237-8.

12. Karaca AS, Özmen MM, Uçar AD, et al. General surgery operating room practice in patients with COVID-19. Turkish Journal of Surgery. 2020;36:1-5

13. Kamer E Çolak T. What to Do when a patient infected with COVID-19 needs an operation: a pre-surgery, peri-surgery and post-surgery guide. Turkish J Color Dis. 2020;30(1):1-8.

14. Çelik B, Yasak K, Turhan Damar H, et al. Covid-19 Salgınında Ameliyathane Ve VakYönetimi. J Anatolia Nurs Heal Sci. 2020;23(2):328-39.

15. Nguyen LH, Drew DA, Graham MS et al. Risk of COVID-19 among front-line health-care workers and the general community: a prospective cohort study. Lancet Public Heal. 2020;5(9):475-483.

16. Alajmi J, Jeremijenko AM, Abraham JC, et al. COVID-19 infection among healthcare workers in a national healthcare system: The Qatar experience. Int J Infect Dis. 2020;100:386-9.

17. Guo X, Wang J, Hu D, et al. Survey of COVID-19 disease among orthopaedic surgeons in Wuhan, people's republic of china. J Bone Joint Surg Am. 2020;102(10):847-54. 
18. Koh D. Occupational risks for COVID-19 infection. Occupational Medicine. 2020;70:3-5.

19. Gümüş $K$ and Basgün $A$. Evaluation of the Knowledge of Operating Room Nurses on Preventive Practices for Protection Against COVID-19. J PeriAnesthesia Nurs. 2020; Article in press.

20. McIntosh K. Coronavirus disease 2019 (COVID-19): Epidemiology, virology, and prevention [Internet]. UpToDate. 2020 [cited 2021 Jan 3]. Available from: https://www.uptodate.com/contents/ coronavirus-disease-2019-covid-19-epidemiology-virology-andprevention

21. Fuchs $A$, Lanzi $D$, Beilstein $C M$, et al. Clinical recommendations for in-hospital airway management during aerosol-transmitting procedures in the setting of a viral pandemic. Best Pract Res Clin Anaesthesiol. 2020;8:1-5.

22. Fennelly KP. Particle sizes of infectious aerosols: implications for infection control. The Lancet Respiratory Medicine. 2020; 8: 914-24.

23. Cook TM, El-Boghdadly K, McGuire B, et al. Consensus guidelines for managing the airway in patients with COVID-19: Guidelines from the difficult airway society, the association of anesthetists the intensive care society, the faculty of intensive care medicine and the royal college of anesthetists. Anaesthesia. 2020;75(6):785-99.

24. Bartoszko JJ, Farooqi MAM, Alhazzani W, Loeb M. Medical masks vs N95 respirators for preventing COVID-19 in healthcare workers: A systematic review and meta-analysis of randomized trials. Influenza Other Respi Viruses. 2020;14(4):365-73.

25. Chen $Q$, Liang $M$, Li Y, et al. Mental health care for medical staff in China during the COVID-19 outbreak. The Lancet Psychiatry. 2020;7:15-6.

26. Halcomb E, McInnes S, Williams A, et al. The Experiences of primary healthcare nurses during the COVID-19 pandemic in Australia. J Nurs Scholarsh. 2020; 52(5):553-63.

27. Savoia E, Argentini G, Gori D, et al. Factors associated with access and use of PPE during COVID-19: A cross-sectional study of Italian physicians. PLoS One. 2020;15(10):e0239024.

28. Schwartz J, King CC and Yen MY. Protecting healthcare workers during the coronavirus disease 2019 (covid-19) outbreak: Lessons from Taiwan's severe acute respiratory syndrome response. Clin Infect Dis. 2020;71(15):858-60.

29. Ferioli M, Cisternino C, Leo V, et al. Protecting healthcare workers from sars-cov-2 infection: Practical indications. Eur Respir Rev. 2020;29(155):1-10.

30. Elizabeth Brindle M and Gawande A. Managing COVID-19 in surgical systems. Ann Surg. 2020;272(1). 